\title{
EXPOSURE TO SELECTED PATHOGENS IN GEOFFROY'S CATS AND DOMESTIC CARNIVORES FROM CENTRAL ARGENTINA
}

\author{
Marcela M. Uhart, ${ }^{1,4}$ M. Virginia Rago, ${ }^{1}$ Carolina A. Marull, ${ }^{1}$ Hebe del Valle Ferreyra, ${ }^{1}$ and \\ Javier A. Pereira ${ }^{2,3}$ \\ ${ }^{1}$ Global Health Program, Wildlife Conservation Society, Amenabar 1595, Ciudad de Buenos Aires (C1426AKC), \\ Argentina \\ ${ }^{2}$ CONICET_Museo Argentino de Ciencias Naturales "Bernardino Rivadavia", Av. Ángel Gallardo 470, \\ Ciudad de Buenos Aires (C1405DJR), Argentina \\ ${ }^{3}$ Asociación para la Conservación y el Estudio de la Naturaleza (ACEN) \\ ${ }^{4}$ Corresponding author (email: muhart@ wcs.org)
}

ABSTRACT: Wild carnivores share a high percentage of parasites and viruses with closely related domestic carnivores. Because of increased overlap and potential contact with domestic species, we conducted a retrospective serosurvey for 11 common carnivore pathogens in 40 Geoffroy's cats (Leopardus geoffroyi) sampled between 2000 and 2008 within or near two protected areas in central Argentina (Lihué Calel National Park, La Pampa, and Campos del Tuyú National Park, Buenos Aires), as well as five domestic cats and 11 domestic dogs from cattle ranches adjacent to Lihué Calel Park. Geoffroy's cats had detectable antibody to canine distemper virus (CDV), feline calicivirus (FCV), feline coronavirus, feline panleukopenia virus (FPV), Toxoplasma gondii, Leptospira interrogans (serovars Ictero/Icter and Ballum), and Dirofilaria immitis. None of the wild cats had antibodies to feline herpesvirus, feline immunodeficiency virus (FIV), feline leukemia virus, or rabies virus. Domestic dogs had antibodies to CDV, canine adenovirus, canine herpesvirus, and canine parvovirus. Antibodies to FPV, FCV, FIV, and T. gondii were found in domestic cats. We provide the first data on exposure of free-ranging Geoffroy's cats to pathogens at two sites within the core area of the species distribution range, including the first report of antibodies to CDV in this species. We encourage continued monitoring for diseases in wild and domestic carnivores as well as preventive health care for domestic animals, particularly in park buffer zones where overlap is greatest.

Key words: Argentina, domestic carnivores, domestic-wild interface, Leopardus geoffroyi, pathogens, serosurvey.

\section{INTRODUCTION}

Threats to the health of wildlife resulting from anthropogenic influence are often associated with increased contact between wildlife and domestic animals (Laurenson et al., 1998; Cleaveland et al., 2000). This interaction is facilitated by increasing human populations and changes in land use that restrict suitable habitat for wildlife and forces the coexistence of wild and domestic animals (Bengis et al., 2002). Wild carnivores are especially susceptible to parasites, viruses, and bacteria that affect closely related domestic cats and dogs (Pedersen et al., 2007). Greater risks exist in areas of potential range overlap, such as protectedarea buffer zones (Cleaveland et al., 2000).

The Geoffroy's cat (Leopardus geoffroyi) is a small felid (4 kg) distributed from southern Brazil and Bolivia throughout southern Patagonia in Argentina and Chile (Nowell and Jackson, 1996). Habitat loss and poaching are probably the main current threats to Geoffroy's cat survival, though further research is needed to understand the impact of several other threats within its range. Exposure to infectious diseases has been poorly evaluated in free-ranging Geoffroy's cats. However, a serologic survey by Fiorello et al. (2007) that included nine Geoffroy's cats from Bolivia near the northern limit of the species' distribution revealed that this felid is not naïve to pathogens shared with domestic carnivores and of conservation concern. Examples include feline panleukopenia virus (FPV), feline calicivirus (FCV), and canine distemper virus (CDV), which are highly contagious, persistent in the environment, and capable of infecting multiple host species, rendering them particularly relevant for wild carnivore conservation. To better understand the exposure of Geoffroy's cats to common carnivore pathogens, we conducted 

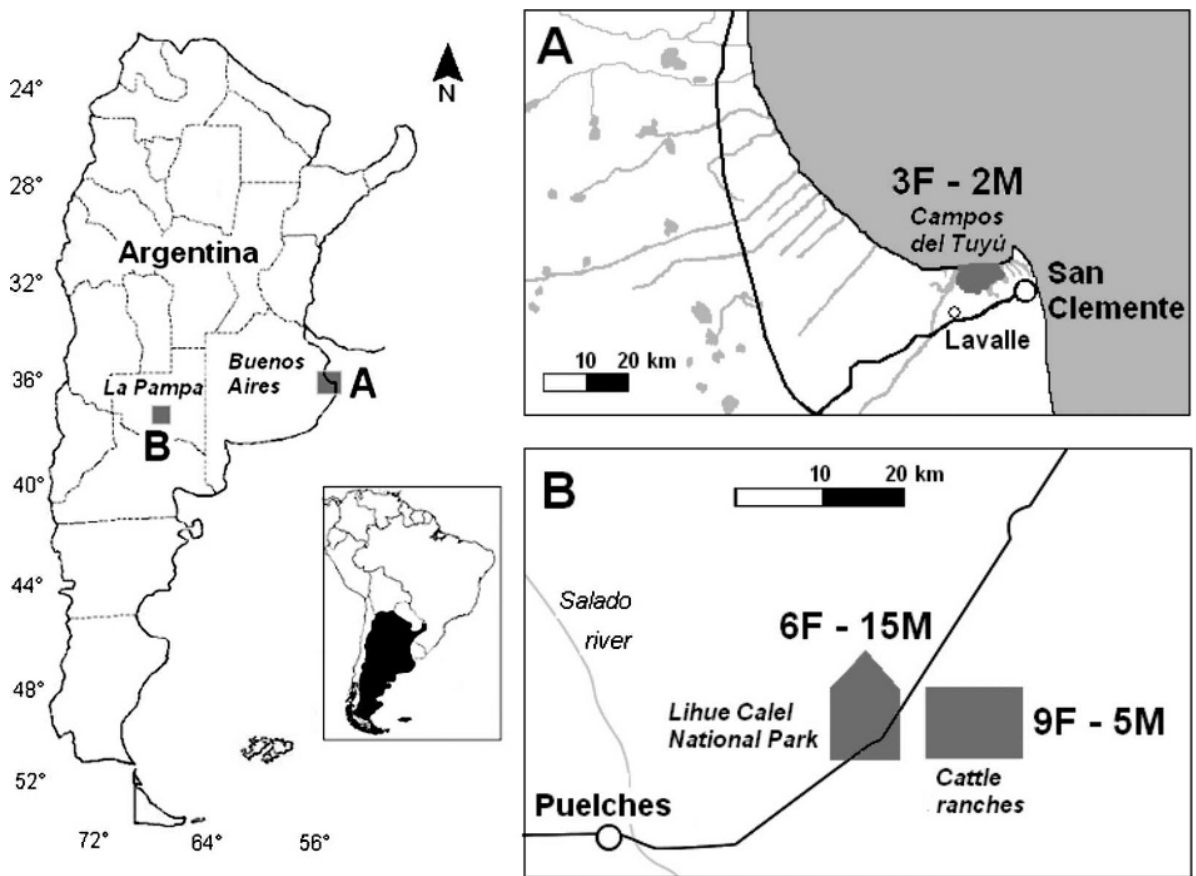

Figure 1. Geoffroy's cat (Leopardus geoffroyi) sample collection sites from Buenos Aires (A. Campos del Tuyú National Park) and La Pampa (B. Lihué Calel National Park and neighboring ranches) provinces in Argentina. Towns and cities near sampling sites are provided for reference. Numbers and sex $(\mathbf{M}=\operatorname{male} ; \mathbf{F}=$ female) of Geoffroy's cats sampled at each site are included.

a retrospective serosurvey at two sites in central Argentina, within the core distribution area for this species. In one of these sites, we also conducted an exploratory serosurvey of domestic cats and dogs living near the reserve limits.

\section{MATERIALS AND METHODS}

Most Geoffroy's cats were captured and sampled within and around Lihué Calel National Park (hereafter Lihué, $100 \mathrm{~km}^{2}, 37^{\circ} 57^{\prime} \mathrm{S}$, $\left.65^{\circ} 33^{\prime} \mathrm{W}\right)$ in La Pampa Province, Argentina. Additionally, a subset of Geoffroy's cats sampled during a previous study at Campos del Tuyú National Park (hereafter Tuyú, $30 \mathrm{~km}^{2}, 36^{\circ} 15^{\prime} \mathrm{S}$, $\left.56^{\circ} 55^{\prime} \mathrm{W}\right)$ in Buenos Aires Province have been included for comparison (Fig. 1).

Tuyú is a coastal marsh area, with a mosaic of dense natural grasslands, isolated tree patches, and numerous estuarine streams and lagoons (Faggi and Cagnoni, 1993). The park is surrounded by cattle ranches and two small cities are nearby. Predation on native wildlife by feral dogs is a major conservation concern in this area (Vila and Beade, 1997). Lihué consists of a set of bare rock hills surrounded by a plain of desert scrub. Vegetation is an assortment of creosote bush (Larrea sp.) flats, mixed shrub patches, and open areas. The park is completely surrounded by large cattle ranches (mode $=$ $50 \mathrm{~km}^{2}$ ) that dominate the regional landscape (Pereira, 2009). Ranchers keep domestic animals $(2.4 \pm 1.1 \mathrm{SD}$ dogs and 2.4 $\pm 2.3 \mathrm{SD}$ cats per ranch; $n=17$ ranches; Pereira, 2009). Dogs are often used to hunt wildlife in the vicinity of the park, but occasionally enter the park and prey on felids (Pereira et al., 2010). Geoffroy's cats occasionally prey upon domestic poultry they attack in farmers' backyards and chicken coops (Pereira, 2009).

Geoffroy's cats were captured in Tomahawk box traps (Tomahawk Live Trap Company, Tomahawk, Wisconsin, USA) and homemade box traps. Trapped cats were immobilized with a combination of $10 \mathrm{mg} / \mathrm{kg}$ of tiletamine and zolazepam (Telazol; Butler Schein Animal Health, Dublin, Ohio, USA) in Tuyú and a combination of $6 \mathrm{mg} / \mathrm{kg}$ ketamine hydrochloride (Ketaset; Butler Schein Animal Health) and $0.1 \mathrm{mg} / \mathrm{kg}$ medetomidine (Domitor; Orion Corporation Farmos, Espoo, Finland) in Lihué (Uhart, unpubl. data). Atipamezole (Antisedan, Orion Corporation Farmos) was used to antagonize medetomidine. 
Five Geoffroy's cats (three females and two males) were sampled at Tuyú in February 2000 and 35 (15 females and 20 males) were sampled at Lihué in two different periods $(2002-2003 n=10$, and 2007-2008 $n=25)$. Of the cats sampled at Lihué, 21 were captured within the national park and 14 in adjacent cattle ranches. All were adults, except for one young male (6-8 mo old) from Lihué, and appeared to be in good physical condition at capture (i.e., no apparent disease), although body weights of cats captured in Lihué in 2003 were slightly lower (8\%) than those captured in 2007-2008 (Pereira, 2009). Blood samples were collected by venipuncture of the jugular, cephalic, or saphenous veins in heparinized syringes, and centrifuged at $1,100 \times \mathrm{G}$ (Mobilespin, model 128, Cardinal Health, Dublin, Ohio, USA) in the field within $4 \mathrm{hr}$ of collection. Plasma was stored in liquid nitrogen in the field, and transferred to a $-20 \mathrm{C}$ freezer until exported for analysis.

All sampling events in Lihué (see below), and particularly in 2003, coincided with periods of severe prolonged drought that led to significant food shortage for Geoffroy's cats (Pereira et al., 2006). As a result, six cats included in this study were found dead 1-3 mo after capture (Pereira et al., 2006; Pereira, 2009). Gross and histologic findings in dead cats were consistent with poor nutritional status and included emaciation (low body weight, loss of subcutaneous and pericardial fat, hepatic fatty change) and high parasite loads (Beldoménico et al., 2005). Clinical or histologic signs consistent with infectious disease were not observed. This scenario coupled with postmortem findings suggests that the dead cats were severely affected by the lack of prey.

Domestic cats (four females and one male) and domestic dogs (two females and nine males) were sampled in May-July 2007 in cattle ranches near Lihué, except for a 12-year-old female domestic cat that belonged to a park ranger based at the national park. This cat was the only vaccinated animal in this study. It was vaccinated $11 \mathrm{yr}$ before the study with one dose of inactivated triple vaccine for feline herpesvirus (FHV), FPV, and FCV (Felocell, Pfizer). All domestic animals appeared to be in good physical condition and were adults at the time of sampling, except for one young male dog $(4 \mathrm{mo})$ and one female cat $(6 \mathrm{mo})$. Domestic carnivores were manually restrained with the assistance of their owners, and blood samples were collected, processed, and stored as described above. Because samples from Tuyú were collected previously for another study that did not include the assessment of diseases at the domestic-wild interface, there were no domestic animal samples from this area.

Geoffroy's cats were tested for antibodies to FHV, FPV, FCV, CDV, feline coronavirus (FcoV), feline immunodeficiency virus (FIV), feline leukemia virus $(\mathrm{FeLV})$, rabies, Toxoplasma gondii, Leptospira interrogans (serovars Pomona, Hardjo, Icterohaemorrhagiae/ Copenhageni, Grippotyphosa, and Canicola), and Dirofilaria immitis. Thirteen additional serovars of L. interrogans (Australis, Pyrogenes, Bratislava, Sejroe, Javanica, Szwajizak, Saxoebing, Ballum, Icterohaemorrhagiae/Icterohaemorrhagiae, Wolffi, Autumnalis, Bataviae, and Tarassovi) were tested only on Geoffroy's cats sampled in 2007-2008 $(n=25)$.

Domestic cats were tested for the same diseases as Geoffroy's cats, except for rabies. Domestic dogs were tested for CDV, canine adenovirus (CAV), canine herpesvirus (CHV), canine parvovirus (CPV), and D. immitis. All serologic tests were performed at Cornell Veterinary Diagnostic Laboratory, Ithaca, New York, and test methods and cutoff values are shown in Table 1. Antibody prevalence for the most common pathogens was compared between sexes using a Fisher's exact test. Also, we compared antibody prevalence between park and ranches in Lihué using chi-square tests of homogeneity for $2 \times 2$ contingency tables (Daniel, 1990).

\section{RESULTS}

Geoffroy's cats were positive for seven of 11 infectious agents studied (details on location, sex, and titers are provided in Table 2). Serologic tests for FIV, FeLV, rabies, and FHV were negative. In Tuyú, all five Geoffroy's cats were positive for antibody to T. gondii and FCV, two (40\%) to FPV, and one (20\%) to CDV (Table 2). One adult had detectable antibody titers against these four pathogens, one for three, and the remaining three individuals for two of them.

In Lihué, 22 of 35 (63\%) Geoffroy's cats had antibody to FCV, $14(40 \%)$ to $T$. gondii, seven $(20 \%)$ to $\mathrm{CDV}$, two $(6 \%)$ to FPV, and one (3\%) to FcoV (Table 2). In addition, 15 of $25(60 \%)$ had antibody to $L$. interrogans serovar Ictero/Icter, two (8\%) to serovar Ballum, and one individual (3\%) was positive for adult $D$. immitis antibody (Table 2). Thirty Geoffroy's cats (86\%) 
TABLE 1. Serologic tests and positive cutoff values used by Cornell Veterinary Diagnostic Laboratory, Ithaca, New York, USA to detect exposure of Geoffroy's cats (Leopardus geoffroyi) and domestic carnivores to selected disease agents.

\begin{tabular}{|c|c|c|}
\hline Pathogen & Test method ${ }^{\mathrm{a}}$ & Positive titer ${ }^{\mathrm{b}}$ \\
\hline Canine adenovirus & SN & $\geq 4$ \\
\hline Canine distemper virus & SN & $\geq 8$ \\
\hline Canine herpesvirus & SN & $\geq 8$ \\
\hline Canine parvovirus & $\mathrm{HI}$ & $\geq 20^{\circ}$ \\
\hline Feline calicivirus & $\mathrm{SN}$ & $\geq 8$ \\
\hline Feline coronavirus & KELA & $\geq 8$ \\
\hline Feline herpesvirus & $\mathrm{SN}$ & $\geq 8$ \\
\hline Feline immunodeficiency virus (FIV) & KELA & $\mathrm{P} / \mathrm{N}$ \\
\hline FIV confirmatory & WB & $\mathrm{P} / \mathrm{N}$ \\
\hline Feline leukemia virus & ELISA & $\mathrm{P} / \mathrm{N}$ \\
\hline Feline panleukopenia virus & $\mathrm{HI}$ & $\geq 20^{\mathrm{c}}$ \\
\hline Rabies & RFFIT & $\geq 5$ \\
\hline Dirofilaria immitis (occult) & I-ELISA & $\mathrm{P} / \mathrm{N}$ \\
\hline Leptospira interrogans & MAT & $\geq 100$ \\
\hline Toxoplasma gondii & KELA & $\geq 48$ \\
\hline
\end{tabular}

${ }^{\text {a }} \mathrm{SN}=$ serum neutralization; $\mathrm{HI}$ = hemagglutination inhibition; KELA = kinetic enzyme-linked immunosorbent assay; $\mathrm{WB}=$ Western blot; ELISA = enzyme-linked immunosorbent assay; RFFIT $=$ rapid fluorescent focus inhibition test; IELISA $=$ indirect enzyme-linked immunosorbent assay; MAT $=$ microscopic agglutination test.

${ }^{\mathrm{b}} \mathrm{P} / \mathrm{N}=$ test scored as positive or negative.

${ }^{\mathrm{c}}$ In domestic carnivores positive titers are $\geq 10$.

from Lihué had antibodies for at least one of the 11 agents tested, with one (3\%) being positive for four agents, six $(17 \%)$ to three, $17(49 \%)$ to two, and six (17\%) to only one agent.

Prevalences between females and males were not significantly different $(P>0.05)$. Overall prevalences (and 95\% confidence interval) for antibody to the three most represented pathogens in Lihué Geoffroy's cats (FCV: 64\% [43-84] in the park and $62 \%$ [35-88] in ranches; L. interrogans serovar Ictero/Icter: 53\% [28-79] in the park and 70\% [42-98] in ranches; $T$. gondii: $45 \%$ [25-66] in the park and $31 \%$ [6-56] in ranches) were not significantly different $(P>0.05)$ between park and ranches.

Of the 11 domestic dogs sampled, 10 $(91 \%)$ were positive to CPV antibody, six (55\%) to CAV, four $(36 \%)$ to $\mathrm{CDV}$ and CHV, and none to D. immitis (Table 3). Domestic cats were positive for four (FPV, FCV, FIV, and T. gondii) of nine antibodies, with a single positive for each except for FPV (four of five animals were antibody positive). A single domestic cat (a 12-year-old vaccinated female) had antibody to three of these agents (FPV, FCV, and FIV; Table 4).

\section{DISCUSSION}

We provide the first data on exposure of Geoffroy's cats to selected infectious agents at two sites in Argentina, within the core area of the distribution range of this species. Our results show evidence of exposure to $4 / 11$ and $7 / 11$ pathogens in Tuyú and Lihué, respectively. Positive titers to FCV and FPV were also found by Fiorello et al. (2007) in a Geoffroy's cat population near the northern limit of the species distribution in Bolivia. Similarly to these authors, we detected that Geoffroy's cats in Lihué are exposed to various pathogens common to domestic carnivores with which they overlap.

For FCV, high titers (up to 768 in four individuals) and high antibody prevalence (100\% and $62.8 \%$ at Tuyú and Lihué, respectively) were found in Geoffroy's cats. Feline calicivirus is extremely contagious, especially in areas with high felid 
TABLE 2. Site and year of sampling and antibody titers found in five Geoffroy's cats (Leopardus geoffroyi) from Campos del Tuyú National Park, Buenos Aires, and 35 from Lihué Calel National Park, La Pampa, Argentina, evaluated for exposure to selected pathogens. All Geoffroy's cats were negative to feline herpesvirus, feline immunodeficiency virus, feline leukemia virus, and rabies. ${ }^{a}$

\begin{tabular}{|c|c|c|c|c|c|c|c|c|c|c|c|}
\hline Locality & Site & Year & ID & Sex & FCV & $\mathrm{FCoV}$ & FPV & $\mathrm{CDV}$ & $\mathrm{Li}$ & $\mathrm{Di}$ & To \\
\hline \multirow{5}{*}{$\begin{array}{l}\text { Campos del } \\
\text { Tuyú }\end{array}$} & \multirow{5}{*}{$\begin{array}{l}\text { National } \\
\text { Park }\end{array}$} & \multirow[t]{5}{*}{2000} & 1 & $\mathrm{~F}$ & 48 & - & - & - & - & - & 62 \\
\hline & & & 2 & $\mathrm{~F}$ & 48 & - & - & - & - & - & 66 \\
\hline & & & 3 & M & 768 & - & - & - & - & - & 56 \\
\hline & & & 4 & $\mathrm{~F}$ & 512 & - & 160 & 24 & - & - & 57 \\
\hline & & & 5 & M & 256 & - & 640 & - & - & - & 50 \\
\hline \multirow{35}{*}{ Lihué Calel } & \multirow{22}{*}{$\begin{array}{c}\text { National } \\
\text { Park }\end{array}$} & \multirow[t]{4}{*}{2002} & 6 & M & 768 & - & - & 16 & - & - & 57 \\
\hline & & & 7 & M & 768 & 12 & - & 128 & - & - & 65 \\
\hline & & & 8 & M & 48 & - & - & - & - & - & - \\
\hline & & & 9 & $\mathrm{~F}$ & - & - & - & - & NT & NT & 60 \\
\hline & & \multirow[t]{3}{*}{2003} & $12^{\mathrm{b}}$ & $\mathrm{F}$ & 128 & - & - & 2,048 & NT & NT & 115 \\
\hline & & & $14^{\mathrm{b}}$ & $\mathrm{F}$ & 128 & - & - & - & - & - & - \\
\hline & & & $16^{\mathrm{b}}$ & $\mathrm{F}$ & 48 & - & - & - & - & - & 63 \\
\hline & & \multirow[t]{10}{*}{2007} & 20 & M & - & - & - & - & - & - & - \\
\hline & & & 21 & M & 8 & - & - & - & - & - & 56 \\
\hline & & & 22 & M & 24 & - & - & - & - & - & 49 \\
\hline & & & 23 & M & 12 & - & - & - & 100 & - & - \\
\hline & & & 24 & M & - & - & - & - & 100 & - & 62 \\
\hline & & & 25 & M & - & - & - & - & - & - & - \\
\hline & & & 26 & $\mathrm{~F}$ & 8 & - & - & - & - & - & 56 \\
\hline & & & 27 & M & - & - & - & - & - & - & - \\
\hline & & & 28 & M & - & - & - & - & 200 & - & 69 \\
\hline & & & 33 & M & - & - & - & - & - & - & - \\
\hline & & \multirow[t]{5}{*}{2008} & 42 & $\mathrm{~F}$ & - & - & - & 128 & 400 & NT & - \\
\hline & & & 43 & $\mathrm{~F}$ & 8 & - & 20 & - & 400 & NT & - \\
\hline & & & 44 & M & 16 & - & - & - & 200 & NT & - \\
\hline & & & 45 & M & 12 & - & - & 192 & 200 & NT & - \\
\hline & & & 46 & M & 48 & - & - & - & 200 & NT & - \\
\hline & \multirow{13}{*}{$\begin{array}{l}\text { Cattle } \\
\text { ranches }\end{array}$} & \multirow[t]{3}{*}{2003} & $17^{\mathrm{b}}$ & $\mathrm{F}$ & 48 & - & - & - & - & POS & - \\
\hline & & & $18^{\mathrm{b}}$ & $\mathrm{F}$ & 512 & - & - & - & - & - & - \\
\hline & & & $19^{\mathrm{b}}$ & $\mathrm{F}$ & 768 & - & - & 256 & - & - & - \\
\hline & & \multirow[t]{8}{*}{2007} & 29 & $\mathrm{~F}$ & - & - & - & - & - & - & - \\
\hline & & & 30 & M & 8 & - & - & - & 100 & - & - \\
\hline & & & 31 & $\mathrm{~F}$ & 32 & - & - & - & 200 & - & 86 \\
\hline & & & 32 & M & - & - & - & - & 100 & - & - \\
\hline & & & 35 & $\mathrm{~F}$ & 16 & - & - & - & 200 & - & - \\
\hline & & & 36 & M & 24 & - & - & - & - & - & 56 \\
\hline & & & 37 & $\mathrm{~F}$ & - & - & - & - & - & - & 225 \\
\hline & & & 39 & M & - & - & - & 32 & 200 & - & 137 \\
\hline & & \multirow[t]{2}{*}{2008} & 40 & M & - & - & 20 & - & 100 & NT & - \\
\hline & & & 41 & $\mathrm{~F}$ & 8 & - & - & - & 400 & NT & - \\
\hline
\end{tabular}

${ }^{\mathrm{a}} \mathrm{NT}=$ not tested; POS = positive; - = negative; FCV = feline calicivirus; FcoV = feline coronavirus; FPV $=$ feline panleukopenia virus; $\mathrm{CDV}=$ canine distemper virus; $\mathrm{Li}=$ Leptospira interrogans (serovars positives Ictero/Icter and Ballum); $\mathrm{Di}=$ Dirofilaria immitis; To $=$ Toxoplasma gondii .

${ }^{\mathrm{b}}$ Found dead at a later date (see text for reference).

densities (Lenghaus et al., 2001). Geoffroy's cats occur at high densities in Lihué (up to 120 individuals per $100 \mathrm{~km}^{2}$; Pereira et al., 2011) and Tuyú (Lucherini et al., 2000), probably resulting in high contact rates among individuals, thus explaining the high antibody prevalences. High titers of antibodies to FCV $(\geq 500)$ were observed in $15 \%$ of the animals (6/40), suggesting an active response to the virus at the time of sampling. Feline calicivirus infection can produce disease character- 
TABlE 3. Antibody titers to selected pathogens in 11 domestic dogs sampled in 2007 around Lihué Calel National Park, Argentina. All dogs were negative to Dirofilaria immitis.

\begin{tabular}{|c|c|c|c|c|c|c|}
\hline \multirow[b]{2}{*}{ ID } & \multirow[b]{2}{*}{ Sex } & \multirow[b]{2}{*}{ Age (yr) } & \multicolumn{4}{|c|}{ Pathogens evaluated ${ }^{\mathrm{a}}$} \\
\hline & & & CAV & CHV & CPV & CDV \\
\hline 1 & M & 0.4 & Negative & 16 & 1,280 & Negative \\
\hline 2 & M & 1.5 & Negative & Negative & 1,280 & Negative \\
\hline 3 & M & 1.8 & Negative & Negative & 1,280 & Negative \\
\hline 4 & $\mathrm{~F}$ & 0.8 & Negative & Negative & 160 & Negative \\
\hline 5 & M & 3.5 & 128 & Negative & 1,280 & Negative \\
\hline 6 & $\mathrm{~F}$ & 1.6 & 192 & Negative & 640 & 192 \\
\hline 7 & M & 1.2 & 768 & Negative & 640 & 192 \\
\hline 8 & M & 1 & Negative & Negative & Negative & Negative \\
\hline 9 & M & 3 & 64 & 256 & 160 & 48 \\
\hline 10 & M & 3 & 1,536 & 16 & 320 & Negative \\
\hline 11 & M & 5 & 2,048 & 24 & 160 & 1,024 \\
\hline
\end{tabular}

${ }^{\mathrm{a}} \mathrm{CAV}=$ canine adenovirus; $\mathrm{CHV}=$ canine herpesvirus; $\mathrm{CPV}=$ canine parvovirus; $\mathrm{CDV}=$ canine distemper virus.

ized by vesicles, erosion, and ulceration of oral cavity and muzzle epithelium, conjunctivitis, rhinitis, tracheitis, or pneumonia (Lenghaus et al., 2001). However, no clinical signs of disease were observed in sampled individuals and the absence of macro- and microscopic lesions in the six necropsied animals with FCV antibodies (titer range $=6-768$ ) suggests previous or repeated exposure to this agent and the probability that FCV is endemic in these populations. At least for the Lihué site, the low FCV antibody prevalence detected in domestic cats indicates that the infection circulates in Geoffroy's cats independently of the domestic cat population. Antibodies to FCV have been reported in several free- ranging wild felid species in America and Africa, but clinical disease has not been described (Lenghaus et al., 2001).

All Geoffroy's cats sampled in Tuyú were positive for $T$. gondii antibodies and the prevalence in Lihué was also high (40\%). Warm-blooded animals are reservoirs of $T$. gondii in nature and the most likely mode of infection is by ingestion of infected prey or transplacentally (Hill and Dubey, 2002). Since Geoffroy's cat diet in both Lihué (Bisceglia et al., 2008; Pereira et al., 2012) and Tuyú (Vuillermoz, 2001) consists mostly of rodents and other small vertebrates, ingestion is the most likely route of exposure, though infection in prey has not been evaluated. Conversely, prevalence in

TABLE 4. Antibody titers to selected pathogens in five domestic cats sampled in 2007 around Lihué Calel National Park, Argentina. All domestic cats were negative to feline leukemia virus, feline coronavirus, canine distemper virus, feline herpesvirus, and Leptospira interrogans. Four cats were negative to Dirofilaria immitis (cat 4 was not tested).

\begin{tabular}{ccccccc}
\hline & & & \multicolumn{4}{c}{ Pathogens evaluated $^{\text {a }}$} \\
\cline { 4 - 6 } ID & Sex & Age $(\mathrm{yr})$ & FCV & FPV & To & FIV \\
\hline 1 & $\mathrm{~F}$ & 1 & Negative & 20 & Negative & Negative \\
2 & $\mathrm{~F}$ & 0.6 & Negative & 10 & 484 & Negative \\
3 & $\mathrm{~F}$ & 0.6 & Negative & Negative & Negative & Negative \\
4 & $\mathrm{M}$ & 1 & Negative & 10 & Negative & Negative \\
5 & $\mathrm{~F}^{\mathrm{b}}$ & 12 & 128 & 2,560 & Negative & Positive $^{\mathrm{c}}$ \\
\hline
\end{tabular}

${ }^{a}$ FCV = feline calicivirus; FPV = feline panleukopenia virus; To = Toxoplasma gondii FIV = feline immunodeficiency virus.

${ }^{\mathrm{b}}$ Vaccinated with one dose of inactivated triple vaccine for feline herpesvirus, FPV, and FCV in 1996 (Felocell, Pfizer).

c Positive/negative test. 
domestic cats was lower than expected given that they mostly live outdoors and hunt for their food, which would facilitate exposure. Infection with Toxoplasma spp. is common in felids, whereas clinical disease is rare (Dubey et al., 1987), and therefore is unlikely to represent a significant threat to wild felid populations (Ramos-Silva et al., 2001).

Antibodies to CDV were found in both Geoffroy's cat populations studied, and one cat in Lihué had a high positive titer $(2,048)$. This animal was one of six found dead postcapture. However, though clinical signs have been reported in wild felids with lower titers (i.e., 1,445, Daoust et al., 2009), no clinical or postmortem (macro- or microscopic) signs of disease were observed in this cat, except for emaciation and a body mass loss of over $40 \%$ between capture and death, 40 days later. Nevertheless, tissues in which histologic evidence of distemper can be seen, such as brain and lungs, were not available for histologic examination because of the poor condition of the carcass when found. Therefore, the significance of this finding remains unknown. All other CDV antibody-positive Geoffroy's cats showed titers similar to those reported for asymptomatic freeranging lynx (Daoust et al., 2009).

Four of 11 domestic dogs were serologically positive for CDV. Domestic dogs are considered a source of CDV and, in some cases, have been implicated in large mortality events of wild felids (lions, Panthera leo; Roelke-Parker et al., 1996) or wild canids (African wild dogs, Lycaon pictus; Alexander and Appel, 1994). Crabeating fox (Cerdocyon thous) deaths attributed to CDV of domestic dog origin have recently been documented in Argentina (Ferreyra et al., 2009). Because of the wide host range of this virus (Williams, 2000) and the presence of other susceptible wild carnivores in our study areas such as the Pampas fox (Lycalopex gymnocercus), the hog-nosed skunk (Conepatus chinga), and the lesser grison (Galictis cuja), identifying the source of exposure to CDV for
Geoffroy's cats is unlikely. Although CDV susceptibility appeared to be confined to large felids, on the basis of findings in bobcats (Lynx rufus) and domestic cats, Munson (2001) indicates that this is no longer the case. Nonetheless, the absence of signs in the Geoffroy's cats sampled in this study, even in those with high antibody titers, suggests that these individuals developed protective neutralizing antibodies. However, it is possible that part of the population was affected at the time of exposure to this pathogen, and only survivors were sampled in this study. To the best of our knowledge, this is the first report of exposure to CDV in free-ranging Geoffroy's cats. The impact of this virus on Geoffroy's cat populations remains unknown and merits further investigation due to its high conservation relevance.

Antibodies to FPV were found in asymptomatic Geoffroy's cats at both Tuyú and Lihué. Antibodies to this virus have been documented in free-ranging populations of felids, including Geoffroy's cats from Bolivia (Fiorello et al., 2007). Mortality with clinical signs has been reported in freeranging bobcats (Wassmer et al., 1988), whereas fatal cases in captive Eurasian lynx (Lynx lynx) and European wildcat (Felis silvestris) have been associated with outbreaks in coexisting domestic cats (Wasieri et al., 2009). Eighty percent of domestic cats tested in Lihué were positive for FPV antibody with low titers $(\leq 20)$, whereas one 12-year-old vaccinated female living inside the park had high titers but no clinical signs, suggesting recent contact with the virus. Although FPV is very pathogenic for felids, does not require direct contact for transmission, and can persist for long periods in the environment (Barker and Parrish, 2001), antibody prevalence in coexisting Geoffroy's cats was low $(6 \%)$. Nevertheless, two of five Geoffroy's cats had detectable antibody to FPV in Tuyú, but information on domestic carnivore prevalence from this area is lacking. Given that parvoviruses are potent immunogens, higher prevalences and titers 
would be expected if Geoffroy's cats were repeatedly exposed (Barker and Parrish, 2001). Therefore, viral circulation in sympatric domestic cats suggested by the prevalences observed is a cause for concern for Geoffroy's cat conservation.

Prevalence of $\mathrm{FcoV}$ in free-ranging felids is reported to be near $2 \%$ (Evermann and Benfield, 2001). Illness and associated death have only been described in captive felids and these cases included animals that were antibody negative, although the virus was detected in their feces through PCR (Heeney et al., 1990; Kennedy et al., 2002). Thus, even though only one Geoffroy's cat in our study had antibodies to this virus, the possibility that other exposed individuals may not have been detected by serologic methods should be considered. Exposure to a coronavirus in cheetahs (Acinonyx jubatus) has been thought to result from contact with domestic cats or from crossreactions with other (non-FcoV) antigenically similar coronaviruses of dietary origin (i.e., from feral swine; Heeney et al., 1990). The wild boar (Sus scrofa) was introduced in Argentina in the late 1800s and is present in both Lihué and Tuyú (Novillo and Ojeda, 2008). Nonetheless, it has never been detected as prey for Geoffroy's cats in these areas (Vuillermoz, 2001; Bisceglia et al., 2008). Even though FcoV is highly species-specific, cross-infection between wild and domestic carnivores has been reported (Evermann et al., 1980; Ballou, 1993). However, the lack of FcoV antibodies in domestic cats and the low antibody titer (12) in the only positive Geoffroy's cat renders this finding irrelevant.

Evidence of heartworm (D. immitis) infection in a Geoffroy's cat from Lihué was unexpected, as this parasite is normally associated with tropical and subtropical climates that are favorable for the reproduction of mosquito vectors. Consequently, D. immitis has been reported in free-ranging carnivores from the tropics (Nakagaki et al., 2000; Deem and Emmons, 2005). Nevertheless, the geographic distribution of $D$. immitis seems to be expanding into temperate areas (Bowman et al., 2009; Genchi et al., 2009). In Argentina, D. immitis is thought to not reach latitudes $>34^{\circ}$ (Vezzani et al., 2011). The necropsy and subsequent histology of the positive cat confirmed severe emaciation and high parasite loads, but filaria were not seen in the lungs even though the carcass was very fresh. Although larvae or adult worms provide a definitive postmortem diagnosis of infection, ectopic location of the parasite can hinder diagnosis (Kalkstein et al., 2000). Further studies are needed to assess the potential implications of this finding.

The lack of antibodies to FHV and FIV in Geoffroy's cats sampled in this study contrast with reported antibody prevalence in cats from Bolivia (Fiorello et al., 2007). Only an old domestic cat, also positive for FPV, was serologically positive for FIV with a high titer $(2,560)$. According to Yamamoto et al. (1989), high enzyme-linked immunoassay titers are a strong indicator of active FIV infection. However, given that this animal was negative upon confirmatory Western blot test and that repeated samples were not available, our results are inconclusive.

We found evidence of exposure to seven pathogens in Geoffroy's cats, three of which were shared with domestic animals. In Lihué, however, prevalence did not differ between the ranches (where all people have cats and dogs) and the park (where domestic carnivores are rare). These results may be partially explained by the existence of pathogen sources in the area other than domestic carnivores, as was previously suggested for $T$. gondii. An alternative (or complementary) explanation might be related to Geoffroy's cat spatial ecology at the time of this study. Radiocollared cats showed an active movement pattern, with long mean daily movements (up to $5 \mathrm{~km}$ ), frequent longdistance emigrations (up to $130 \mathrm{~km}$ ), and periodic shifts in home ranges (Pereira et al., 2006; Pereira, 2009). Exposed cats dispersing to and from ranches could have transmitted infections to new areas where 
domestic carnivores were absent. Furthermore, the severe drought that affected Lihué during parts of this study could have affected pathogen environmental survival and consequent infectivity (Greene et al., 1998; Barker and Parrish, 2001).

Studies on the basis of antibody titers such as this do not allow for the identification of active infection during sampling or the time at which study animals were exposed. Nonetheless, our findings highlight the importance of continued monitoring for diseases at the wild-domestic interface, particularly in protected-area buffer zones where overlap is greatest. Given that park boundaries do not provide protection from pathogen spillover between domestic and wild carnivores, preventive health care of domestic animals (such as vaccinations) in and around parks should be implemented to avoid disease transmission.

\section{ACKNOWLEDGMENTS}

We thank all volunteers, colleagues, park rangers, and ranchers for assistance during sample collection. P. Beldoménico and two anonymous reviewers provided helpful comments that improved the manuscript. D. McAloose performed histologic analysis. G. Porini and E. Fernandez assisted with permits, and G. Aprile and N. Fracassi provided support during several stages of this work. Research permits were granted by Administración de Parques Nacionales, Fundación Vida Silvestre Argentina, and La Pampa and Buenos Aires provinces. This study was funded by WCSGlobal Health Program, The Rufford Foundation, Cleveland Metroparks Zoo-Cleveland Zoological Society, and Roger Williams Park Zoo.

\section{LITERATURE CITED}

Alexander, K. A., And M. J. G. Appel. 1994. African wild dogs (Lycaon pictus) endangered by a canine distemper epizootic among domestic dogs near the Masai Mara National Reserve, Kenya. Journal of Wildlife Diseases 30: 481-485.

BALlou, J. D. 1993. Assessing the risks of infectious disease in captive breeding and reintroduction programs. Journal of Zoo and Wildlife Medicine 24: 327-335.

Barker, I. K., AND C. R. Parrish. 2001. Parvovirus infections. In Infectious diseases of wild mammals, E. S. Williams and I. K. Barker (eds.). 3rd Edition.
Iowa State University Press, Ames, Iowa, pp. 131-146.

Beldoménico, P. M., J. M. Kinsella, M. M. Uhart, G. L. Gutierrez, J. A. Pereira, H. V. Ferreyra, and C. A. Marull. 2005. Helminths of Geoffroy's cat, Oncifelis geoffroyi (Carnivora, Felidae) from the Monte Desert, central Argentina. Acta Parasitologica 50: 263-266.

Bengis, R. G., R. A. Kock, and J. Fischer. 2002. Infectious animal diseases: The wildlife/livestock interface. Revue Scientifique et Technique 21: 53-65.

Bisceglia, S. B. C., J. A. Pereira, P. Teta, and R. D. Quintana. 2008. Food habits of Geoffroy's cat (Leopardus geoffroyi) in the central Monte desert of Argentina. Journal of Arid Environments 72: 1120-1126.

Bowman, D., S. E. Little, L. Lorentzen, J. Shields, M. P. Sullivan, and E. P. Carlin. 2009. Prevalence and geographic distribution of Dirofilaria immitis, Borrelia burgdorferi, Ehrlichia canis, and Anaplasma phagocytophilum in dogs in the United States: Results of a national clinicbased serologic survey. Veterinary Parasitology 160: 138-148.

Cleaveland, S., M. J. Appel, W. S. K. Chalmers, C. Chillingworth, M. KaAre, and C. Dye. 2000. Serological and demographic evidence for domestic dogs as a source of canine distemper virus infection for Serengeti wildlife. Veterinary Microbiology 72: 217-227.

Daniel, W. W. 1990. Applied nonparametric statistics. 7th Edition. PWS-Kent, Boston, Massachusetts, $755 \mathrm{pp}$.

Dhoust, P. Y., S. R. McBurney, D. L. Godson, M. W. G. van de Bildt, and A. D. Osterhaus. 2009. Canine distemper virus-associated encephalitis in free-living lynx (Lynx canadensis) and bobcats (Lynx rufus) of Eastern Canada. Journal of Wildlife Diseases 45: 611-624.

Deem, S. L., and L. H. Emmons. 2005. Exposure of free-ranging maned wolves (Chrysocyon brachyurus) to infectious and parasitic disease agents in the Noël Kempff Mercado National Park, Bolivia. Journal of Zoo and Wildlife Medicine 36: 192-197.

Dubey, J. P., W. J. Quinn, and D. Weinandy. 1987. Fatal neonatal toxoplasmosis in a bobcat (Lynx rufus). Journal of Wildlife Diseases 23: 324-327.

Evermann, J. F., AND D. A. Benfield. 2001. Coronaviral infections. In Infectious diseases of wild mammals, E. S. Williams and I. K. Barker (eds.). 3rd Edition. Iowa State University Press, Ames, Iowa, pp. 245-253.

, W. Foreyt, L. MaAg-Miller, C. W. Leathers, A. J. McKeirnan, and B. Leamaster. 1980. Acute hemorrhagic enteritis associated with canine coronavirus and parvovirus infection in a captive coyote population. Journal of the American Medical Association 177: 784-786. 
FagGi, A. M., And M. Cagnoni. 1993. La vegetación de la reserva de vida silvestre Campos del Tuyú. Parodiana 8: 101-112.

Ferreyra, H., M. G. Calderon, D. Marticorena, C. Marull, and L. Barrios Caro. 2009. Canine distemper infection in crab-eating fox (Cerdocyon thous) from Argentina. Journal of Wildlife Diseases 45: 1158-1162.

Fiorello, C. V., A. J. Noss, S. L. Deem, L. Maffei, AND E. J. Dubovi. 2007. Serosurvey of small carnivores in the Bolivian Chaco. Journal of Wildlife Diseases 43: 551-557.

Genchi, C., L. Rinaldi, M. Mortarino, M. Genchi, and G. Cringoli. 2009. Climate and Dirofilaria infection in Europe. Veterinary Parasitology 163: 286-292.

Greene, C. E., M. A. Miller, and C. A. Brown. 1998. Leptospirosis. In Infectious diseases of the dog and cat, C. E. Greene (ed.). 2nd Edition. W. B. Saunders, Philadelphia, Pennsylvania, pp. 273-282.

Heeney, J. L., J. F. Evermann, A. J. McKeirman, L. Marker-Kraus, M. E. Roelke, M. Bush, D. E Wild, G. Meltzer, L. Colly, J. Lukas, V. J. Manton, T. Caro, ANd S. J. O’Brien. 1990. Prevalence and implications of feline coronavirus infections of captive and free-ranging cheetahs (Acinonyx jubatus). Journal of Virology 64: 1964-1972.

Hill, D., And J. P. Dubey. 2002. Toxoplasma gondii: Transmission, diagnosis and prevention. Clinical Microbiology and Infection 8: 634-640.

Kalkstein, T. S., L. Kaiser, and J. B. Kaneene. 2000. Prevalence of heartworm infection in healthy cats in the Lower Peninsula of Michigan. Journal of the American Veterinary Medical Association 217: 857-861.

Kennedy, M., S. Citino, A. H. McNabb, A. S. Moffatt, K. Gertz, and S. Kania. 2002. Detection of feline coronavirus in captive Felidae in the USA. Journal of Veterinary Diagnostic Investigation 14: 520-522.

Laurenson, K., C. Sillero-Zubiri, H. Thompson, F. Shiferaw, S. Thirgood, and J. Malcolm. 1998. Disease as a threat to endangered species: Ethiopian wolves, domestic dogs, and canine pathogens. Animal Conservation 1: 273-280.

Lenghaus, C., M. J. Studdert, and D. Gavier-Widen. 2001. Calicivirus infections. In Infectious diseases of wild mammals, E. S. Williams and I. K. Barker (eds.). 3rd Edition. Iowa State University Press, Ames, Iowa, pp. 280-291.

Lucherini, M., L. Soler, C. Manfredi, A. Desviez, and C. Marull. 2000. Geoffroy's cats in the pampas grassland. Cat News 33: 22-24.

Munson, L. 2001. Feline Morbilivirus infection. In Infectious diseases of wild mammals, E. S. Williams and I. K. Barker (eds.). 3rd Edition. Iowa State University Press, Ames, Iowa, pp. 59-62.
NaKagaki, K., T. SuZuki, S. I. Hayama, and E. Kanda. 2000. Prevalence of dirofilarial infection in raccoon dogs in Japan. Parasitology International 49: 253-256.

Novillo, A., and R. OJeda. 2008. The exotic mammals of Argentina. Biological Invasions 10: 1333-1344.

Nowell, K., and P. Jackson. 1996. Wild cats. Status survey and conservation action plan. IUCNSpecies Survival Commission-Cat Specialist Group, Gland, Switzerland, 382 pp.

Paul-Murphy, J., T. Work, D. Hunter, and E. MCFIE. 1994. Serological survey and serum biochemical reference ranges of free-ranging mountain lions (Felis concolor) in California. Journal of Wildlife Diseases 30: 205-215.

Pedersen, A. B., K. E. Jones, C. L. Nunn, and S. A. Altizer. 2007. Infectious disease and mammalian extinction risk. Conservation Biology 21: 1269-1279.

Pereira, J. A. 2009. Efectos del manejo ganadero y disturbios asociados sobre la ecología trófica y espacial y la demografía del gato montés (Leopardus geoffroyi) en el desierto del Monte, Argentina. Ph.D. Thesis, Universidad de Buenos Aires, Buenos Aires, Argentina, 196 pp.

-, N. G. Fracassi, and M. M. Uhart. 2006. Numerical and spatial responses of Geoffroy's cat (Oncifelis geoffroyi) to prey decline in Argentina. Journal of Mammalogy 87: 1132-1139.

- V. Rago, H. Ferreyra, C. A. Marull, D. McAloose, and M. M. Uhart. 2010. Causes of mortality in a Geoffroy's cat population-A long-term survey using diverse recording methods. European Journal of Wildlife Research 56: 939-942.

, M. S. Di Bitetti, N. G. Fracassi, A. Paviolo, C. D. De Angelo, Y. E. Di Blanco, and A. J. Novaro. 2011. Population density of Geoffroy's cat in scrublands of central Argentina. Journal of Zoology 283: 37-44.

, R. S. Walker, and A. J. Novaro. 2012. Effects of livestock on the feeding and spatial ecology of Geoffroy's cat. Journal of Arid Environments 76: 36-42.

Ramos-Silva, J. C., S. Ogassawara, C. H. Adania, F. Ferreira, S. M. Gennari, J. P. Dubey, and J. S. Ferreira-Neto. 2001. Seroprevalence of Toxoplasma gondii in captive neotropical felids from Brazil. Veterinary Parasitology 102: 217-224.

Roelke-Parker, M. E., L. Munson, C. Parker, R. Kock, S. Cleaveland, M. Carpenter, S. J. O’Brien, A. Pospischil, R. Hofmann-Lehmann, H. Lutz, G. L. M. Mwamengele, M. N. Mgasa, G. A. Machange, M. A. Summers, and M. J. G. Appel. 1996. A canine distemper virus epidemic in Serengeti lions (Panthera leo). Nature 379: 441-445.

Vezzani, D., A. E. Carbajo, M. F. Fontanarrosa, C. F. Scodellaro, J. Basabe, G. Cangiano, and D. F. Eiras. 2011. Epidemiology of canine 
heartworm in its southern distribution limit in South America: Risk factors, interannual trend and spatial patterns. Veterinary Parasitology 176: 240-249.

Vila, A. R., AND M. S. Beade. 1997. Situación de la población del venado de las pampas en la Bahía Samborombón. Boletín Técnico FVSA N ${ }^{\circ} 37$, Buenos Aires, Argentina, 30 pp.

Vuillermoz, P. A 2001. Dieta estacional y selección de presas del gato montés (Oncifelis geoffroyi) y zorro pampeano (Pseudalopex gymnocercus) en la Reserva de Vida Silvestre Campos del Tuyú. $\mathrm{BcS}$ Thesis, Universidad de Buenos Aires, Buenos Aires, Argentina, 54 pp.

Wasieri, J., G. Schmiedeknecht, C. Förster, M. König, and M. Reinacher. 2009. Parvovirus infection in a Eurasian lynx (Lynx lynx) and in a European wildcat (Felis silvestris silvestris). Journal of Comparative Pathology 140: 203-207.
Wassmer, D. A., D. D. Guenther, and J. N. Layne. 1988. Ecology of the bobcat in south-central Florida. Bulletin of the Florida State Museum of Biological Sciences 33: 159-228.

Williams, E. S. 2000. Canine distemper. In Infectious diseases of wild mammals, E. S. Williams and I. K. Barker (eds.). 3rd Edition. Iowa State University Press, Ames, Iowa, pp. 50-59.

Yamamoto, J. K., H. Hansen, E. W. Ho, T. Y. Morishita, T. Okuda, T. R. Sawa, R. M. Nakamura, and N. C. Pedersen. 1989. Epidemiologic and clinical aspects of feline immunodeficiency virus infection in cats from the continental United States and Canada and possible mode of transmission. Journal of the American Veterinary Medical Association 194: 213-220.

Submitted for publication 19 May 2011. Accepted 6 June 2012. 